\title{
Ochrona wartości przestrzennych i kulturowych Śródmieścia Lublina poprzez zachowanie modernistycznego gmachu Powszechnego Domu Towarowego w Lublinie
}

\author{
Karol Krupa ${ }^{1}$, Maciej Trochonowicz ${ }^{2}$ \\ ${ }^{1}$ Samodzielna Pracownia Architektoniczna, Wydziat Budownictwa i Architektury, \\ Politechnika Lubelska, e-mail: k.krupa@pollub.pl \\ ${ }^{2}$ Katedra Konserwacji Zabytków, Wydział Budownictwa i Architektury, \\ PolitechnikaLubelska,e-mail:m.trochonowicz@pollub.pl
}

Streszczenie: Artykuł porusza kwestię ochrony wartości przestrzennych i kulturowych Śródmieścia Lublina. Analiza kompozycyjna oraz funkcjonalna istniejącej zabudowy uwzględniającej modernistyczny gmach Powszechnego Domu Towarowego skłania do dyskusji na temat konieczności ingerencji we wskazaną tkankę miejską. Wartość „dodana”, efekt synergii, objawia się w efektach uzyskanych poprzez zachowanie istniejącej zabudowy, nadanie jej nowej wartości użytkowej przy poszanowaniu i uwydatnieniu wzajemnych relacji pomiędzy pierwotną funkcją,estetyką i kompozycją przestrzenną. Tadeusz Witkowski projektując w 1959 roku Powszechny Dom Towarowy (PDT) zmierzył się z lokalizacją wielkopowierzchniowej funkcji handlowej w ścisłym Centrum miasta Lublin. Wyczucie przez architekta kompozycji bryły, zrozumienie przestrzeni i zachowanie skali otaczającej zabudowy przyczyniło się do podkreślenia wartościowych osi widokowych i kompozycyjnych. W 2010 r. spółka inwestorska, właściciel budynku PDT, przedstawiła plan wyburzenia modernistycznego gmachu i powstania w tym miejscu nowoczesnej galerii handlowej. Dyskusja na temat przyszłości spuścizny Witkowskiego podzieliła środowisko lubelskich architektów. Jedną z form sprzeciwu i jego argumentacji były Warsztaty „Reaktywacja”, które odbyły się przy współpracy „Modernizmu w Lublinie” (inicjatywa mgr inż. arch. Marcina Semeniuka) oraz Studenckiego Koła Naukowego Architektury Współczesnej Politechniki Lubelskiej w 2015r. [1]. Młodzi architekci i studenci opracowali koncepcję adaptacji budynku PDT uwzględniające uatrakcyjnienie funkcji handlowej oraz wprowadzenie nowych, nastawionych na potrzeby i rozwój mieszkańców Lublina. Bazę koncepcji stanowił projekt Tadeusza Witkowskiego, który został rozbudowany zgodnie z wytycznymi uchwalonego dla tego obszaru Miejscowego Planu Zagospodarowania Przestrzennego [2]. Omówione zagadnienia związane z problematyką ochrony, analizą wartości przestrzennej i kulturowej oraz udział inicjatyw społecznych w dialogu na temat przyszłości Powszechnego Domu Towarowego w Lublinie są rozpatrywane przez autora jako działania, których efektem jest synergia na kilku płaszczyznach.

Słowa kluczowe: modernizm powojenny, Powszechny Dom Towarowy w Lublinie, Tadeusz Witkowski, synergia w architekturze.

\section{Zarys problematyki ochrony architektury i sztuki modernistycznej}

Problem ochrony Powszechnego Domu Towarowego jest jednym z bardzo wielu akcentów wyłaniających się z tła jakie tworzy ogólnopolska dyskusja środowiska architektów, 
konserwatorów zabytków i historyków sztuki. Burzliwa polemika dotycząca uznawania obiektów powstałych w krajobrazie miast polskich w XX w., będących przykładami powojennego modernizmu, trwa nieprzerwanie od wielu lat. Niestety nie można mówić o sukcesie objawiającym się $\mathrm{w}$ rozwiązaniu problemu ponieważ wiele przykładów architektury spotyka się z niezrozumieniem jej wartości zarówno w kręgach architektów i historyków sztuki, ale także inwestorów czy codziennych użytkowników i obserwatorów przestrzeni miejskiej. Można natomiast za powodzenie w rozwoju sprawy uznać fakt co raz większego zaangażowania grup powstałych z inicjatyw społecznych. Tym bardziej cieszy rzecz, jeżeli zainteresowani operują merytorycznymi i logicznymi argumentami uzasadniając swoją postawę oraz działania związane $\mathrm{z}$ ochroną, w tym przypadku, powojennego modernizmu. Świadome zabranie głosu w dyskusji jest efektem przygotowania z zakresu historii architektury i sztuki, ale również pewnego rodzaju wrażliwością na prezentowaną estetykę oraz sposób organizacji przestrzeni w różnej skali. Celowo już we wstępie uwagę kieruję na mobilizację osób nie spośród grona specjalistów mających bezpośredni wpływ na teorię i praktykę konserwatorską, ale na działaczy społecznych. Ich starania można uznać za głos reprezentujący opinię przynajmniej części odbiorców przestrzeni miejskiej i obiektów ją tworzących. Należy pamiętać o podziale wśród społeczeństwa, z którego wyłaniają się zarówno zwolennicy jak również zagorzali przeciwnicy „realizacji minionego okresu”, stąd określenie „części odbiorców”. Niesława budynków modernistycznych wynika z bardzo powierzchownym kojarzeniem ich z epoką PRL [3]. Konsekwencją zawiłości historycznych jest między innymi sposób postrzegania i oceny walorów estetycznych i artystycznych architektury. Często osąd jest bardzo niesprawiedliwy co przedkłada się na brak wsparcia wystarczająco szerokiego grona.

Należy zwrócić uwagę na różnice w podejściu sympatyków omawianych budynków a inwestorów i właścicieli. Niejednokrotnie jest to sposób postrzegania i analizy wartości bardzo kontrastowy i oparty na skrajnie różnych argumentach i wizji. Bardzo istotne jest otwarte spojrzenie obu grup uczestniczących w dialogu. Znaczącym wątkiem w „debacie” nad przyszłością budynków modernistycznych pozostaje zrozumienie priorytetów właścicieli obiektów w procesie inwestycyjnym. Sposób użytkowania budynków jest decyzją inwestora i jeżeli nie jest sprzeczny z zapisami Miejscowego Planu Zagospodarowania Przestrzennego (lub decyzji o warunkach zabudowy) oraz warunkami określonymi przez konserwatorów zabytków to nic nie stoi na przeszkodzie do realizacji planów. Budynki modernistyczne, co warto zauważyć, są obiektami, które można dostosować do nowej funkcji w sposób mniej problematyczny niż na przykład średniowieczne kamienice. Pozwalają na to założenia, które są podstawami definiującymi ten styl. Wolny plan, konstrukcja oparta na siatce słupów czy też duże przeszklenia dają możliwość kształtowania przestrzeni odpowiedniej dla zróżnicowanego programu funkcjonalnego. Problemy pojawiają się dopiero przy analizie konstrukcji i innych aspektów technicznych. Wykorzystane materiały i rozwiązania nie w każdym przypadku można potraktować zgodnie z zasadami konserwacji zabytków dotyczących ograniczenia interwencji i zachowania oryginalnej struktury [4]. Jednak przy wypracowaniu odpowiednich form i ram dla działań konserwatorskich, które znacząco wpłynęłyby na rozwój całego zagadnienia ochrony obiektów modernistycznych, można byłoby w dużym stopniu wydłużyć ich żywotność i zwiększyć atrakcyjność. Byłby to istotny argument dla inwestorów, którzy nierzadko odnoszą się do niskiej jakości estetycznej stanu istniejącego budynków. W wyniku czego często podejmując decyzje nieodwracalne.

Drugą stroną medalu, na którą powinno się zwracać uwagę jest wartość obiektów modernistycznych dla społeczeństwa i przestrzeni, w której się znajduje i którą współtworzy. Mimo opisanej wcześniej, często niesprawiedliwej oceny walorów artystycznych 
architektury i sztuki modernistycznej, pojawiają się również odbiorcy, którzy są bardzo zagorzałymi zwolennikami spuścizny tej epoki. Dzięki nim nastąpiła w pewnym momencie widoczna promocja i dążenie do akceptacji społecznej przestrzeni i budynków, jak i również szeroko pojętej sztuki utrzymanej w duchu modernizmu. Są to działania przyjmujące różną formę: renowacja neonów reklamowych, mebli i przedmiotów użytku codziennego, ale również adaptacja budynków z zachowaniem ich oryginalnej tkanki i konstrukcji. Przykładem może być remont neonu „Nowe Życie” z Bydgoszczy przez Elżbietę Jabłońską lub napisu „Kosmos” (Adam Brus i Jan Wolski) w Lublinie. Chociaż w drugim przypadku restauracja napisu jest wynikiem nieodwracalnych decyzji o rozbiórce modernistycznego budynku kina w Lublinie. Z powodzeń ratowania „modernizmów” w większej skali na uwagę zasługuje adaptacja dolnego pawilonu kasowego Dworca PKP Powiśle w Warszawie (proj. Arseniusz Romanowicz i Piotr Szymaniak, 1954-1965), w którym grupa projektowa Centrala zaprojektowała obecnie znajdujący się i funkcjonujący bar i miejsce spotkań. Jest to również bardzo dobry przykład na opisany wcześniej szeroki wachlarz możliwości dostosowania architektury modernistycznej do nowej funkcji.

Z drugiej strony obecne zainteresowanie architekturą i sztuką modernizmu we wszystkich etapach jego rozwoju można odebrać jako modę. Dlatego bardzo ważna jest odpowiedź na pytania będące jednocześnie podstawą do odpowiedniej analizy umożliwiającej rozwiązanie problemów, które zawsze towarzyszą tematyce konserwacji i ochrony dziedzictwa:

1. „Czy dziedzictwo modernizmu zasługuje na ochronę?”

2. „Jak wybierać obiekty modernistyczne do ochrony?”

3. „Jakie zasady powinny obowiązywać podczas ochrony architektury modernistycznej?" [5]

Są to pytania, na które odpowiedź wymaga analizy wielu opracowań naukowych i projektowych. Artykuł nie ma na celu bezpośredniego ustosunkowania się do nich na podstawie przypadku Powszechnego Domu Towarowego w Lublinie. Jednak sformułowane w ten sposób zagadnienie pozwoli w pewnym stopniu wyklarować cel i zasadność ochrony budynku.

\section{Wartość kulturowa i przestrzenna Powszechnego Domu Towarowego w Lublinie}

Gmach Powszechnego Domu Towarowego został zaprojektowany przez architekta Tadeusza Witkowskiego w 1959r. Autor pochodził z Lublina gdzie powrócił po studiach na Wydziale Budownictwa Wyższej Szkoły Przemysłowej w Krakowie i Wydziale Architektury Politechniki Warszawskiej. Na przestrzeni lat poświęconych życiu zawodowemu jako projektant $\mathrm{z}$ dynamicznym podejściem do architektury $\mathrm{w}$ znaczny sposób zasłużył się Lublinowi. W swoim dorobku skupił liczne realizacje, które silnie odcisnęły się w przestrzeni miasta. Jednym z takich przykładów były Pawilony Weterynarii - Collegium Veterinarum Uniwersytetu Marii Curie-Skłodowskiej (1953-1959) [4]. Niestety w $2011 \mathrm{r}$. Władze uczelni postanowiły o rozbiórce budynków. Niepokojącym wydaje się fakt, że w opisie i zaleceniach zawartych w Liście Dóbr Kultury Współczesnej znajduje się adnotacja sygnalizująca wskazane zachowanie budynków oraz przywrócenie ich pierwotnego stanu [6]. Jest to informacja istotna dla zagadnienia poruszanego w tym artykule, ponieważ na tej samej liście komisja umieściła budynek PDT określając wytyczne ochrony słowami „pożądana jest adaptacja obiektu $\mathrm{z}$ przystosowaniem do nowych wymogów funkcjonalnych i technologicznych" [7]. Rozpatrując powyższe nasuwa się pytanie o zasadność opracowania i opisanych w nim wytycznych oraz wykorzystanie ich jako argumentacji w staraniach 
o ochronę obiektów w nim umieszczonych. Pawilony weterynarii nie są jedynym przykładem obnażającym brak odniesienia listy do rzeczywistych problemów nasilających się w obliczu rozbiórki lub nieodwracalnych zmian w budynkach spowodowanych niekompetencją podczas przeprowadzanych prac. Warto również przytoczyć zapis, który pojawia się w uwagach ogólnych: „Lista wskazuje obiekty wymagające niewątpliwie ochrony, wszystkie one bowiem są autentycznymi wartościami kultury Lublina i nie powinny być zniszczone". Wyciągnięte $\mathrm{z}$ powyższego wnioski przedstawione $\mathrm{w}$ konfrontacji z pytaniami postawionymi przez profesora Szmygina, wskazują na rozpatrywanie jako istotnych argumentów w ocenie budynków ich wartości wynikających z funkcji jaką odgrywają w kulturze lokalnej.

Powszechny Dom Towarowy zlokalizowany u zbiegu ulic Kapucyńskiej i Krakowskie Przedmieście stanowi bardzo rozpoznawalny punkt w śródmiejskiej części Lublina (Rys. 1). Został zaprojektowany w miejscu hotelu Victoria, który uległ zniszczeniu podczas II Wojny Światowej. Architekt podczas pracy projektowej nad obiektem skonfrontował wymagania nowoczesnej, jak na tamte czasy, funkcji (PDT był pierwszym obiektem handlowym tego typu w Lublinie) $\mathrm{z}$ istniejącą zabudową i tkanką urbanistyczną sąsiadującą z działką przeznaczoną pod galerię. Po analizie architektonicznej i przestrzennej danej lokalizacji na pierwszy plan wysuwa się zabytkowy charakter zabudowy otaczającej teren projektowy zarówno w bliższym jak i dalszym planie. Dominującą rolę odgrywa Kościół oo. Kapucynów, Teatr im. Juliusza Osterwy, które znajdują się w najbliższym sąsiedztwie, oraz Kościół Rektoralny pw Wniebowzięcia Najświętszej Maryi Panny Zwycięskiej i Hotel Europa. Po przeciwległej stronie ul. Kapucyńskiej zachowana pierzeja skomponowana z kamienic mieszczących funkcję mieszkalną z lokalami usługowymi w parterze. Sam Witkowski określa zabudowę w tej części miasta jako wyrównaną gabarytowo [8]. Założenia projektowe i zastały układ urbanistyczny wymagały „związania gabarytów” budynku planowanego i warunkujących je budynków istniejących już w przestrzeni Śródmieścia. Nowoczesny charakter bryły uzyskano dzięki cofnięciu elewacji na poziomie parteru poszerzając jednocześnie chodnik, gdzie zlokalizowano witryny wystawowe i część ekspozycji sklepów (Rys. 2). Dwie kolejne kondygnacje mieszczące sale sprzedaży zostały nadwieszone nad przejściem dla pieszych podkreślając plastycznie mieszczącą się w gmachu funkcję. Całość kompozycji została domknięta najwyższą kondygnacją przeznaczoną na część administracyjną, której elewacja licuje się z linią najniższej części. Dzięki takiemu profilowi zabudowy architekt uzyskał bardzo subtelną, ale i stanowczą, ekspozycję obiektu z obu znaczących dla przestrzeni stron - od Krakowskiego Przedmieścia i ul. Narutowicza. Taki zabieg pozwolił na jednoczesne zaakcentowanie Kościoła Rektoralnego jako dominanty zamykającej oś kompozycyjną ul. Kapucyńskiej (Rys. 3). Witkowski projektując Powszechny Dom Towarowy brał również pod uwagę przyszłą, ale nie zrealizowaną, bryłę Filharmonii Lubelskiej, która miała być kontynuacją Teatru im. Juliusza Osterwy uzupełniającej pierzeję. Mimo luki w zabudowie opisane wcześniej założenie kompozycji jest nadal aktualne i aktywne w sposobie postrzegania przestrzeni. Równie istotnym zabiegiem podkreślającym dostosowanie się do otoczenia było wycofanie elewacji głównej w stosunku do Krakowskiego Przedmieścia. Pozwoliło to na zaakcentowanie bryły kościoła oo. Kapucynów (Rys. 4). 


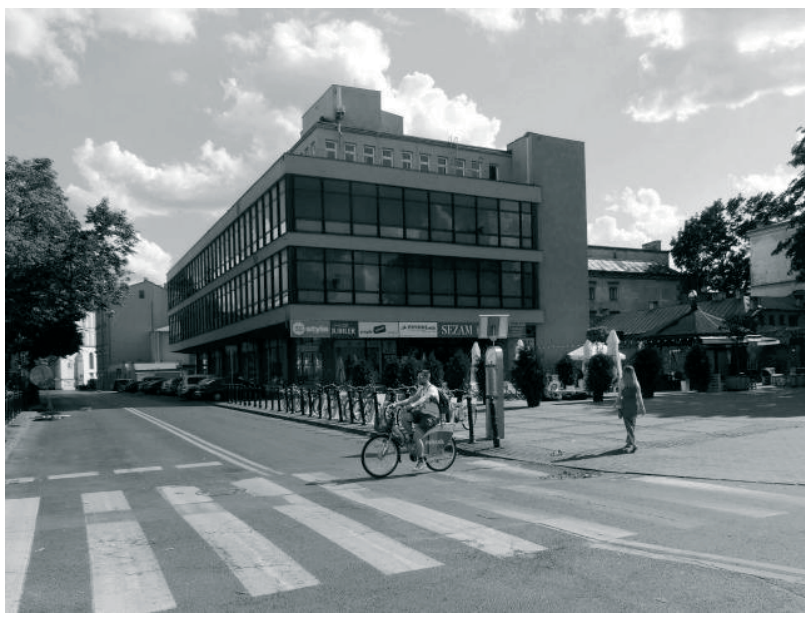

Rys. 1. Widok elewacji wschodniej oraz północnej - frontowej gmachu PDT. Przed budynkiem widoczny plac odsłaniający zabudowania klasztorne. (fot. Marcin Semeniuk)

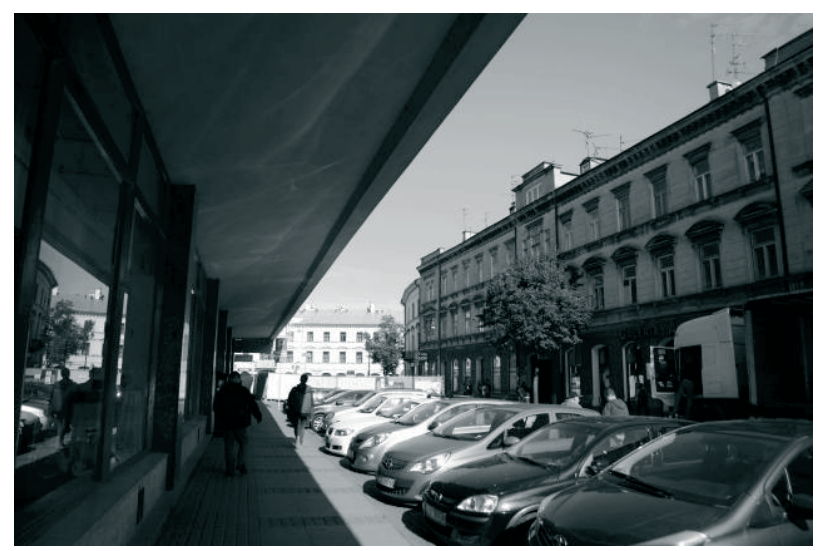

Rys. 2. Widok na kamienice tworzące pierzeję po przeciwnej stronie budynku PDT. Na zdjęciu pokazano podcień osłaniający przejście dla pieszych oraz witryny sklepów. (fot. Autor)

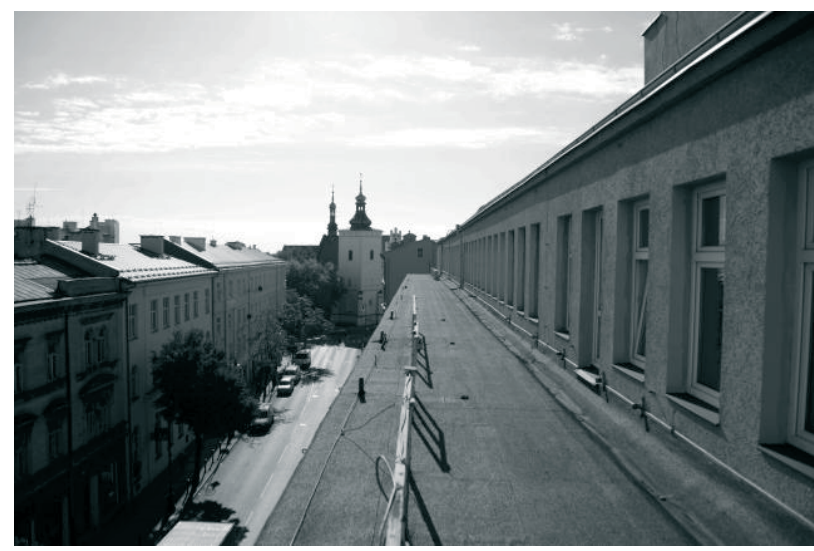

Rys. 3. Widok na Kościół Rektoralny z dachu trzeciej kondygnacji tworzącej nawis od strony ul. Kapucyńskiej. W tle widać Kościół Rektoralny na zamknięciu osi kompozycyjnej. (fot. Autor) 


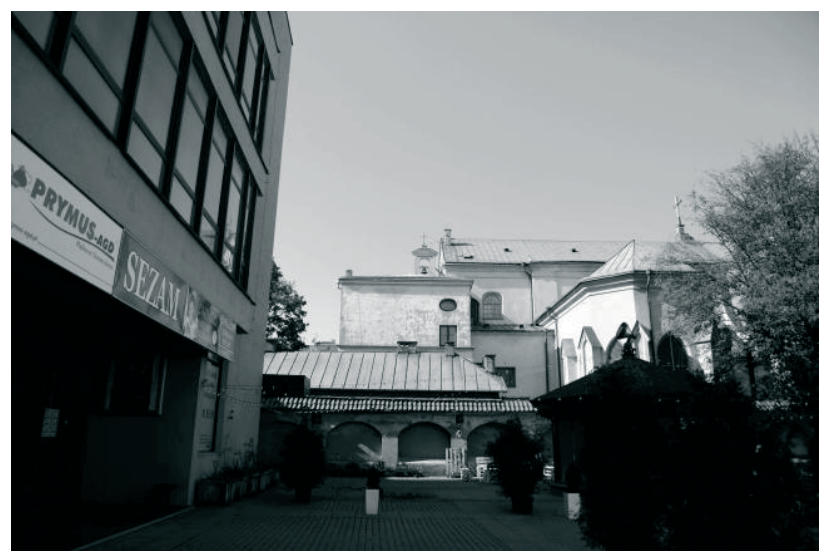

Rys. 4. Widok spod wejścia głównego od Krakowskiego Przedmieścia ukazujący eksponowane budynki klasztoru oo. Kapucynów. (fot. Autor)

W 2010 roku został przedstawiony projekt nowego obiektu usługowo-handlowy, Pasaż Victoria - autorstwa architekta Krzysztofa Ingardena zlokalizowanego w miejscu gdzie obecnie znajduje się Powszechny Dom Towarowy. Projektant w swojej wizji starał się nawiązać do historycznej linii zabudowy, którą tworzył Hotel Victoria. Projekt spotkał się z krytyką Wojewódzkiego Konserwatora Zabytków, która zaznaczyła, że istotnym jest pozostawienie otwartego placu przed budynkiem, od strony Krakowskiego Przedmieścia. Równie niedopuszczalne, wg konserwatora, było doprowadzenie do sytuacji, kiedy nowa bryła będzie zasłaniała sąsiadujący klasztor jednocześnie dominując najbliższe otoczenie. Lista Dóbr Kultury Współczesnej w części dotyczącej warunków ochrony budynku Witkowskiego jasno wskazuje na konieczność zachowania placu przed galerią w takiej formie w jakiej jest obecnie. Dzięki temu zostanie zachowany ład przestrzenny w tej części Śródmieścia, który na tę chwilę jest utrzymany dzięki konsekwencji projektowej realizowanej przed pięćdziesięcioma laty. W 2016 roku, po ośmiu latach od pojawienia się informacji o zbudowaniu nowej galerii handlowej, inwestor przekazał informację, że rezygnuje z dotychczasowych planów. Chociaż nie są znane dalsze zamysły na wykorzystanie potencjału tej działki, istnieje cień szansy, na zachowanie gmachu Powszechnego Domu Towarowego oraz poddanie go należytemu remontowi i dostosowaniu do nowej funkcji, która nie została jeszcze określona przez właścicieli.

\section{Inicjatywa społeczna w ochronie Powszechnego Domu Towarowego w Lublinie}

Wiszące nad Powszechnym Domem Towarowym w Lublinie widmo rozbiórki okazało się mobilizujące do działania na rzecz ochrony obiektu. Głos, który mógłby przyczynić się do poszerzenia horyzontów dyskusji przybrał formę warsztatów skierowanych do adeptów architektury. Celem było opracowanie wizji wprowadzenia nowej funkcji do istniejącego gmachu. Najważniejsze jednak było wyczulenie studentów na problematykę ochrony modernizmu w Polsce na przykładach lubelskich, które z powodu braku zrozumienia estetyki i znaczenia w kontekście miejsca ulegają nieodwracalnym decyzjom i działaniom inwestorskim. Analizując sposób użytkowania budynku na przestrzeni lat oraz uwzględniając potrzeby społeczne, wnioski wypracowane na podstawie rozmów z mieszkańcami Lublina, a także na bazie własnych doświadczeń jako użytkowników przestrzeni 
miejskiej, stworzono trzy koncepcyjne idee zagospodarowania budynku i terenów mu towarzyszących. Zgodnie z intencją i oczekiwaniami organizatorów projekty zakładały pozostawienie galerii w formie istniejącej, a proponowane funkcje były możliwe do rozplanowania $\mathrm{w}$ ramach wypracowanych kompromisów, ale bez naruszenia zrealizowanych założeń Witkowskiego (Rys. 5 i 6).

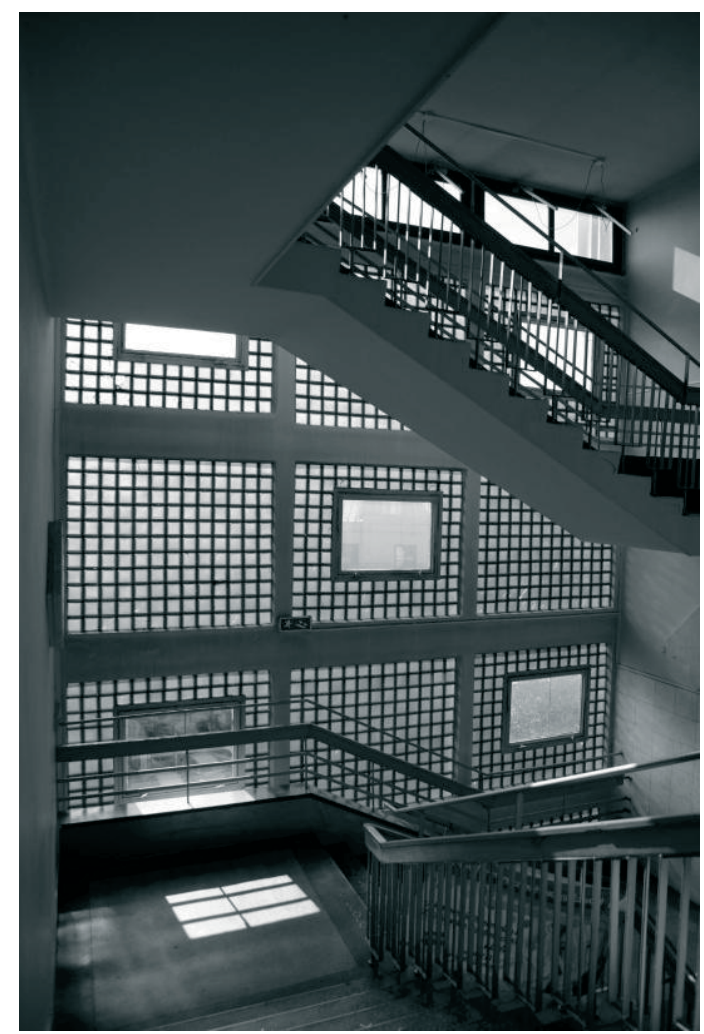

Rys. 5. Doświetlenie południowej klatki schodowej za pomocą luksferów. (fot. Autor)

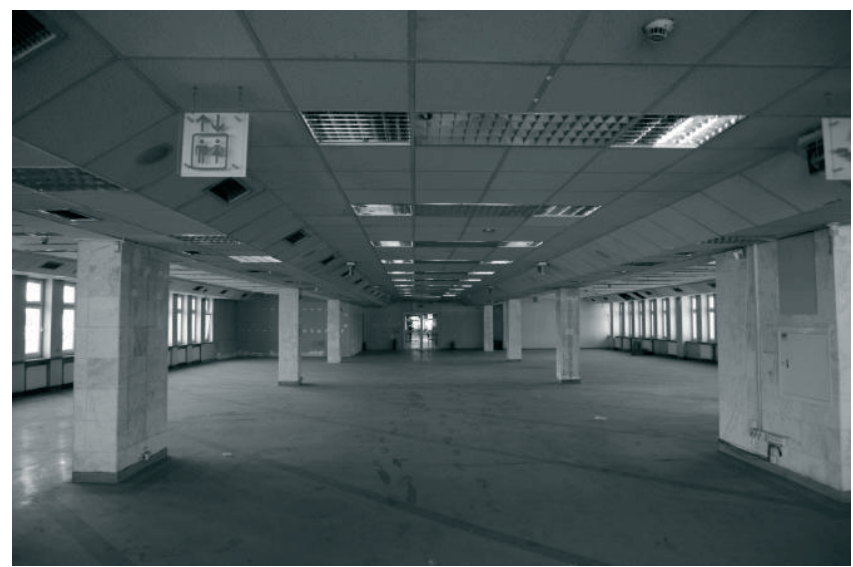

Rys. 6. Wnętrze najwyższej kondygnacji budynku PDT ukazujące układ konstrukcyjny sprzyjający adaptacji na nową funkcję użytkową. (fot. Autor) 


\section{Zachowanie gmachu Powszechnego Domu Towarowego w Lublinie jako przyklad synergii}

Synergią nazywamy zjawisko współgrania elementów lub zjawisk niezależnych od siebie, ale w efekcie końcowym przedstawiających wartość większą niż reprezentują indywidualnie [9]. W opisanym przykładzie Powszechnego Domu Towarowego w Lublinie efekt synergiczny można zauważyć na dwóch płaszczyznach. Oczywisty jest w działaniach na rzecz ochrony, skupiający inicjatywy społeczne, inwestorów oraz grono specjalistów. Podjęcie dialogu wszystkich tych grup, a także analiza możliwości użytkowych istniejącego gmachu może zaowocować zachowaniem obiektu i potwierdzeniem jego wartości dla Śródmieścia Lublina. Skutkiem może być również pojawienie się nowych argumentów w odpowiedzi na problematykę konserwacji architektury modernistycznej. Drugim przejawem synergii jest zależność, której spostrzeżenie można oprzeć na stwierdzeniu Aleksandra Böhma o współgraniu elementów niezależnych [9]. Plastyczna forma organizacji przestrzeni zamkniętej zaprojektowanej przez Tadeusza Witkowskiego wkomponowana w otwartą przestrzeń fragmentu lubelskiego Śródmieścia jest połączeniem ogniw zupełnie skrajnych w swojej definicji, ale doskonale się uzupełniających. Jeżeli można przyjąć, że suma kontrastów daje wynik tożsamy synergii to ochrona Powszechnego Domu Towarowego będzie fizycznym jej przykładem. „Wartością dodaną” jest zachowanie istniejących wartości.

\section{Literatura}

1. Warsztaty z Modernizmem w Lublinie „Reaktywacja” - spotkanie zorganizowane przez kooperatywę społeczną zainicjowaną przez założyciela bloga o tematyce architektonicznej „Modernizm w Lublinie” Marcina Semeniuka wspólnie z Kołem Naukowym Architektury Współczesnej Politechniki Lubelskiej. Materiały przedstawiające efekty warsztatów oczekują publikacji i posłużą jako materiał do dalszej dyskusji na forum.

2. Uchwała nr 72/IV/2015 Rady Miasta Lublin z dnia 26 lutego 2015r. W sprawie uchwalenia miejscowego planu zagospodarowania przestrzennego miasta Lublin - część VIII - Śródmieście w obszarze ulic: Krakowskie Przedmieście, Kapucyńska, Prezydenta Gabriela Narutowicza, Peowiaków, Tadeusza Kościuszki.

3. Kadłuczka A. Ochrona najnowszej architektury „,historycznej”. Wiadomości konserwatorskie 19 (2006) 19-23.

4. Koziej K. Ochrona dziedzictwa powojennego modernizmu. Spotkania z zabytkami 7 (2009) 3-6.

5. Szmygin B. Ochrona architektury modernistycznej - współczesna teoria i praktyka. Modernizm w Europie - modernizm w Gdyni. Architektura lat międzywojennych i jej ochrona, 2009, 161-167.

6. Danczowska H. Architekt T. Witkowski. Kalendarium życia i twórczości. 1904-1986, 2009.

7. Komisja do spraw Opracowania Listy Dóbr Kultury Współczesnej w Lublinie, Architektura, Lista Dóbr Kultury Współczesnej, Lublin, 2011.

8. Witkowski T. Powszechny Dom Towarowy w Lublinie. Architektura SARP 10 (1965) 406-408.

9. Böhm A. O budowie i synergii wnętrz urbanistycznych. Monografia, 1981. 


\title{
Protecting of spatial and cultural value of Downtown Lublin, by maintenance of modernist edifice of the Universal Department Store in Lublin
}

\author{
Karol Krupa ${ }^{1}$, Maciej Trochonowicz ${ }^{2}$ \\ ${ }^{1}$ Independent Architectural Design Studio, Faculty of Civil Engineering and Architecture, \\ Lublin University of Technology,e-mail:k.krupa@pollub.pl \\ ${ }^{2}$ Department of Conservation of Built Heritage, Faculty of Civil Engineering and Architecture, \\ Lublin University of Technology,e-mail: m.trochonowicz@pollub.pl
}

\begin{abstract}
Article raises the issue of protection of spatial and cultural values of Lublin's downtown. Analysis of composition and function of existing building, including modernistic edifice of Powszechny Dom Towarowy is leading to discussion about necessity of intervention in urban fabric. The added value, effect of synergy, is emerging in effects obtained by preserving existing building development, granting it new functional value respecting and bringing out mutual relation between initial function, aesthetic and spatial composition. During the design of PDT in 1959 Tadeusz Witkowski had to face the problem of locating large district area in exact city center of Lublin. Architect's sense of structure composition, understanding of space and bearing scale of existing building contributed to highlight valuable view and composition axis. In 2010 investment company, owner of Powszechny Dom Towarowy building, introduced a plan of demolition existing modernistic edifice and developing new, modern shopping mall. Discussion about future of Witkowski's legacy has divided Lublin's architects community. One form of the objection was workshops, which took place with cooperation of "Modernism in Lublin" (mgr inż arch. Marcin Semeniuk's initiative) and student's scientific organization of Modern Architecture from University of Technology in Lublin in 2015. Young architects and students worked out idea of adaptation of Powszechny Dom Towarowy building considering enchantment of mercantile function and implementation of new, oriented toward needs and progress of Lublin's citizens. Ideabased on Tadeusz Witkowski's project, which was expanded according to guidelines of Local Area Plan. Author of this article considerates the problem of protection edifice of Powszechny Dom Towarowy in Lublin and participation of social initiative as an effect of synergy.
\end{abstract}

Keywords: post-war modernism, Powszechny Dom Towarowy in Lublin, Tadeusz Witkowski, synergy in architecture. 
